\title{
The effect of realia on descriptive text writing quality at the eighth grade students of SMPN 1 Bendo
}

\author{
Risky Alif Widayanti \\ Department of English Teaching, Universitas PGRI Madiun, Indonesia
}

\begin{tabular}{l}
\hline \hline Article Info \\
\hline Article history: \\
Received May 1, 2018 \\
Revised September 22, 2018 \\
Accepted November 29, 2018
\end{tabular}

Keywords:

Writing

Graphic Organizer

Sandwich Graphic Organizer

\begin{abstract}
This research is conducted to explain about the Effect of Realia on Descriptive Text Writing Quality at The Eight Grade Students of SMPN 1 Bendo. The sample of this research are $8-\mathrm{K}$ consisted of 21 students in the eighth grade of SMPN 1 Bendo. The research approach that is used in this study is quantitative. The research was conducted by using experimental research. The data was collected by doing test. The technique of data analysis that is used in this research is paired sample T-test. The result of this research shows that Realia gives significant effect to the students' writing quality in descriptive text. It can be seen that the significant value is 0.000 . It shows that the probabilities value of students' writing skill is lower than 0.05 $(0.000<0.05)$ level of significant. So, the null hypothesis $(\mathrm{H} 0)$ is rejected and the alternative hypothesis (Ha) is accepted. It can be stated that there is significant difference on the students' descriptive text writing skill before being taught using Realia and after being taught using Realia. So, it can be concluded that Realia helps the students in the process of writing descriptive text and this media has positive effect on the students' descriptive text writing quality.
\end{abstract}

Copyright (c) 2018 Department of English Teaching. All rights reserved.

\footnotetext{
Corresponding Author:

Risky Alif Widayanti,

Department of English Teaching,

Universitas PGRI Madiun,

Jalan Setiabudi No.85 Madiun, East Java, Indonesia.

Email: risky.widayanti@yahoo.co.id
}

\section{INTROUCTION}

Writing is one of important language skills. In practice, writing is taught after listening, speaking and reading but it does not mean that learning writing is not important. In fact, writing is very important in learning lessons that is why writing is taught after the third elements are taught and writing also very difficult subject to be mastered. According to Oshima and Hogue (1999:3) state that writing, particularly academic writing is not easy. It takes study and practice to develop this skill. For both native speaker and new learners of English, it is important to note that writing is a process, not a "product". This means that a piece of writing, whether it is a composition for your English class or a lab report for your chemistry class is never completed that is always possible to review and revise, review and revise again.

In the second grade of junior high school, the basic competency that should be achieved by students in the writing English subject is the ability to develop and produce written simple functional text in the descriptive text, recount text, and narrative text. However based on the resercher's observation at the time of the teaching practice program (PPL) the writing ability of grade VIII students at SMP N 1 Bendo still creates disappointment among students themselves as well as teachers. Students have a difficulties to write a descriptive text. In writing descriptive text, the students not only should master the vocabularies but also they 
have to be able to describe someone or something clearly in a detail information. Students who do not master the vocabulary have a mistake in choosing the appropriate vocabulary to describe the characteristic of the object and the students have a difficulty in describing the significant characteristics of the object.

By using an appropriate media in writing descriptive, it will help the students to decribe the objects easier. In fact, English teacher of junior high school usually only asks the students to describe things or just use a picture to help the students write a descriptive text. This usually make them bored because they cannot see the real object they want to describe so they cannot describe the significant characteristics of the object. According to Oshima and Hogue (1996:50), Descriptive writing appeals to the senses, so it tells how something looks, feels, smells, tastes, and/ or sounds. In additon, a good description is like a "word picture"; the reader can imagine the object, place, or person in his or her mind. It means that when the students write a descriptive text, they should use detail words which describe the real object. Although the readers do not see the real object yet, they still can imagine the object in their mind just by read the text. It is not easy to describe something, first of all the students should know the real object in details and sometimes they still forget about the detail description of the object, althougt they have known before.

Based on this case, the researcher thinks that teacher can use realia as a media to improve students's writing quality in descriptive text. According to Herrell \& Jordan (2000:23) defines realia is "a term for real things - concrete objects - that are used in the classroom to build background knowledge and vocabulary." Realia has purpose that is to make students easy to mention the characteristics of the object in detai. Using realia helps students to make English lessons memorable by creating a link between the objects and the word or phrase they represent. So when the students write descriptive paragraph, they will be easy and know what they will write to describe the object by using realia of the object itself. According to Gau, Hyru (2010:vi) "realia provide an excellent tool to help children develop essential English vocabulary, realia enhance meaning and make vocabulary more concrete and therefore, more comprehensible". It means that by using realia it is easier for a students to learn and memoorize about the new vocabulary because the students learn directly by looking the real object or realia.

The researcher found some previous researches related to this research. First, According to Markamah (2013) study entitled “Developing Students' Descriptive Text Writing Ability Through Realia”. By using a quantitative reseach design with pre-test and post-test to measure students' ability in writing descriptive text before treatment and after treatment. The result showed that there was improvement of students' ability in writing descriptive text after treatment using realia as a media. Second, According to Afridah \& Giting (2012) study entitled "Improving The Students' Achivement on Writing Descriptive Text By Using Realia" showed that the students' achievement is improved when they are taught through Realia. By using qualitative and quantitative to collect the data, in the first evaluation increased to the mean of second evaluation and the mean of third evaluation. Observation result showed that the students gave their good atitudes and responses during teaching and learning process by applying the application of Realia.

This research purpose is to know whether there is a significant different on the students' writing skill before and after using Realia on descriptive text at the eight grade students of SMPN 1 Bendo. The researcher will use realia of things (it can be fruits or objects) around them.

\section{METHOD}

English Teaching Journal, Vol. 6, No. 2, December 2018: 91 - 97 
This research entitled, "The Effect of Realia on Descriptive Text Writing Skill of 8th Grade Students of SMP Negeri 1 Bendo" was quantitave research and this research was pre-test and post-test experimental research where the resercher did a research by give a pre-test and post test to one class experiment. First meeting in pre-test, the researcher gave the material as usual or without media then gave a test to the students to make a descriptive text directly. Second meeting, the researcher gave a treatment by using realia media (fruits) to explain a descriptive text material then gave a post test in the last meeting.

The population of this research was the eighth grade students of SMP Negeri 1 Bendo in academic year of 2016/2017. The total number of the population was 231 students who were divided into 11 classes, A, B, C, D, E, F, G, H, I, J, K. The researcher took a sample of this research by choosing one class experiment that was $\mathrm{K}$ class. There were 21 students in $\mathrm{K}$ class. In this research, the researcher evaluated the students' writing based on six aspects of writing. According to Brown (2001:358) there are six aspects evaluated in writing, they are: content, organization, discourse, syntax, vocabulary, mechanic. The following table presents the six aspects of evaluating which was used.

Table 1. Evaluating Student's Writing (Brown, 2001: 358)

\begin{tabular}{ll}
\hline Content & $0-24$ \\
\hline Organization & $0-20$ \\
\hline Discourse & $0-20$ \\
\hline Syntax & $0-12$ \\
\hline Vocabulary & $0-12$ \\
\hline Mechanics & $0-12$ \\
\hline Total & 100 \\
\hline
\end{tabular}

\section{RESULT AND DISCUSSION}

This section provides the results of the research. There are several results relate to the research question. The researcher describes the data result of pre-test and post test. The researcher uses one class experiment, so every student got two scores; pre test and post test. The researcher devides the data into three tables. Table 2 is the data of means score from both test (pre-test and post-test), table 3 is the data of normality test, table 4 is the data of Paired Sample T-test. The data has analyzed by using SPSS 23.0.

Table 2. The students' means score of pre-test and post-test

\begin{tabular}{llrrrr}
\hline & & Mean & N & Std. Deviation & Std. Error Mean \\
\hline Pair 1 & Pretest & 47,43 & 21 & 5,016 & 1,095 \\
& Posttest & 72,95 & 21 & 10,181 & 2,222 \\
\hline
\end{tabular}

The research data of the use of Realia in writing descriptive text shows that before using Realia media to teach and help the students write a descritive text. The mean score of the students bedore using Realia is 47,43 then after using Realia the mean score of the students increase to 72,95 . The increasing of the means score from pre-test to post test is 25,52 . It means that the use of Realia media make the students easier to write a descriptive text.

Table 3. One-Sample Kolmogorov-Smirnov Test

\begin{tabular}{llrr}
\hline & & Pretest & \multicolumn{1}{c}{ Posttest } \\
\hline N & & 21 & 21 \\
& Mean & 47,43 & 72,95 \\
Most Extreme Differences & Std. Deviation & 5,016 & 10,181 \\
& Absolute &, 139 &, 166 \\
& Positive &, 139 &, 122 \\
& Negative &,- 069 &,- 166
\end{tabular}


a. Test distribution is Normal.

b. Calculated from data.

c. Lilliefors Significance Correction.

d. This is a lower bound of the true significance.

Table 3 shows the Normality test analysis from the result output of SPPS 23.0 version program and this research used One-Sample Kolmogorov Smirnov Test (K-S). It can be seen in table 3 that before using Realia in pre-test, the data has a probability (Sig.) 0.200 in which it is more than 0.05 so the pre-test data has a normal distribution. Then from the second data, After doing a treatment by using Realia media in post test, the data has a probability (Sig.) 0.134 in which it is more than 0.05 so the post-test data has a normal distribution. It can be concluded that both of the data are normal.

From Table 4 Paired Sample T-Test above, it can be explained that the value of $t$ is -17.068 with significance value 0.000 . It showed that the Probability value of the students' writing quality is less than 0.05 $(0.000<0.05)$ level of significant. So the null hypothesis $(\mathrm{H} 0)$ is rejected and the alternative hypothesis (Ha) is accepted. It means that there is a significant difference on the means of the students' writing descriptive text quality after using Realia media at the eighth grade students' of SMPN 1 Bendo Magetan.

After analyze the data by using Paired Sample T-Test, it can be interprated that there is a better progress experienced by the students in post-test section. This media make the students easier to express their feelings,

Table 4. Paired Sample T-Test

\section{Paired Differences}

\begin{tabular}{|c|c|c|c|c|c|c|c|c|c|}
\hline & & \multirow{2}{*}{\multicolumn{5}{|c|}{$\begin{array}{c}95 \% \text { Confidence } \\
\text { Interval of the } \\
\text { Difference }\end{array}$}} & \multirow[b]{3}{*}{$\mathbf{t}$} & \multirow[b]{3}{*}{ df } & \multirow{3}{*}{$\begin{array}{l}\text { Sig. (2- } \\
\text { tailed) }\end{array}$} \\
\hline & & & & & & & & & \\
\hline & & Mean & on & Mean & Lower & Upper & & & \\
\hline \multirow[t]{2}{*}{ Pair 1} & Pretest & & & & & & & & \\
\hline & $\begin{array}{l}- \\
\text { Posttest }\end{array}$ & $-25,524$ & 6,853 & 1,495 & $-28,643$ & $-22,404$ & $-17,068$ & 20 & ,000 \\
\hline
\end{tabular}

ideas or opinions about the object that the students described. The students are active in doing the excercises given by the teacher. The students try to describe the object by observing the Realia or real objects. The students are more enthusiastic and more enjoyable in learning process. It can be seen from the result that there is a significant improvement from pre-test to post-test. The students' competence in writing descriptive text increase because of applying Realia media. The students ideas and thoughts about the objects increase by seeing the objects directly. In general, after the treatment, the students' capability in writing descriptve text improve as well. Most of the students can provide more information about what they described. It can be seen from the writing result of the students where they can write more sentences in descriptive text to describe the 
object. The students can organize their idea as well, they know what they write first and next in describing the object. It is different from the result before treatment.

It can be concluded that the result of data analysis in this research shows that the use of Realia or real object gives a significant effect to the students' writing descriptive text quality on the eighth grade students' of SMPN 1 Bendo Magetan in the academic year of 2016/2017. This is also supported by the result of an experimental reseach by Awaliya (2014) entitled "The Effect of Using Real Objects or Realia on the Eight Grade Students' Descriptive Paragraph Writing Achievement at SMP Argopuro 2 Suci Panti Jember in 2013/2014 Academic Year" showing that the use of real object or realia gives a significant effect to the students' writing achievement on the eighth grade students of SMP Argopuro 2 Suci Panti Jember in 2013/2014 academic year. Next, according to the classroom action research by Surbakti \& Saragih (2014) entitled "Improving the Students'chivement In Writing Descriptive Text By Using Realia Strategy" at the eighth grade students of SMP Negeri 1 Salapian showing that the use of Realia strategy makes the teachinglearning process run well, the students are active, enthusiastic and interest in writing descriptive text. The result shows that applying possible sentence strategy significantly improves students' writing achievement.

The use of Realia can stimulate the students thingking and ideas. According to Markamah (2013) study entitled "Developing Students' Descriptive Text Writing Ability Through Realia" shows that there is improvement of students' ability in writing descriptive text after treatment using realia as a media. Further, According to Afridah \& Giting (2012) study entitled "Improving The Students' Achivement on Writing Descriptive Text By Using Realia" shows that the students' achievement improve when they are taught through Realia. Observation result shows that the students give their good atitudes and responses during teaching and learning process by applying the application of Realia. The last, there is a significant effect on students' speaking achievement after being taught by using realia in Susanti (2015) research entitled "The effect of Realia on Students' Speaking Achievement".

The results of some previous researches show that the use of realia or real object gives positive effect to the students' achievement quality not only on writing skill but also in other skill of English. These are in a line with the result of this research that realia or real object is effective media to teach writing descriptive text at the eighth grade students of SMPN 1 Bendo Magetan. The researcher proves that the use of Realia in teaching learning proceess of writing especially in the context of descriptive text give a significant effect on the students' writing quality. But during the implementation of Realia, the researcher finds some problems of applying Realia. Those are:

1. In this reseach, the researcher uses realia of fruits. The researcher brings some kinds of real fruits in the classroom so the students can describe the fruit by seeing the real items. It needs more money or budgets that the teacher should provides to buy some kinds of fruit. Whereas in the real condition, teacher should teach more than one class and the schedule may be in a different day, so it needs much money.

2. There are many kinds of real item realia that provide in the daily life, the shapes or the characteristics of them are different. When the teacher wants to teach about describing animals, sometimes it will be difficult to bring some realia of animal in the classroom. It may because the shape of the animal is big or it is a wild animal that will dangerous to bring in the classroom. 
For those problems of applying Realia in the classroom, the researcher has a solution and suggetion to the teacher who wants applying Realia in the learning process. The solution for the first problem is that actually the teacher uses media is to help the students easier understood the material given by the teacher and make the classroom more enjoyable. To reach that teaching goal, the teacher certainly needs more budget in providing the media than without media. It depends on how the teacher can minimalize the budgets as much as possible. In this case, the use of realia of fruits needs more money. There are some kinds of Realia around the classroom or in daily life so if the teacher wants to minimalize the budgets, the teacher can use real item around the classroom or the students can bring their own favorite things from home. It can be their favorite fruit, food, drink or animal. So the teacher doesn't have a difficulties in bringing some kinds of realia in the classroom because each students have their own real item.

The solution fo the second problem is that in this research the researcher brings realia of fruits in the classroom. The problem is " how if the realia can't bring in the classroom because they are big or dangerous?". If Realia can't bring in the classoom, then the teacher can use a field trip where the students will observe the real things in the real situation or real area. For example when the teacher wants to teach about describing animal, the teacher with the students can go to zoo or farm near the school. This solution also be a suggestion for the next researcher to combining a field trip in applying Realia media. Thus, it is concluded that Realia is effective for teaching descriptive text at the eighth grade students of SMPN 1 Bendo Magetan.

\section{CONCLUSION}

There is a significant difference on the students' descriptive text writing skill after being taught by using realia. It shows from the result of sig.value 0.000 is lower than 0.05 . The students' descriptive text writing skill in the posttest increase after the treatment is given. The students feel enjoy and enthusistic during learing process by using realia. When they try to describe the object by observing the realia, it stimulates their thinking and ideas that they want to describe. They get many more informations when they observe the real items. The students aren't confused about what they should descibe because they can describe by looking the object. So it makes their structure better. Realia is an effective media to teach descriptive text writing and it can be found easier in daily life.

After being taught te students by using realia, there is a significant difference on the means of students' descriptive text writing quality. So, the English teacher is suggested to use this media (realia) in increasing students' writing quality especially on descriptive text. The students can explore the object directly to get some informations by analyzing the real object clearly the describe it into a written form. For the next researcher, it would be better if the next researchers can do a research by combining realia with field trip in context of descriptive text writing.

\section{REFERENCES}

Afridah, I \& Ginting, S.A. (2012). Improving The Students' Achievement on Writing Descriptive Text By Using Realia. REGISTER: Journal of English Language Teaching of FBS UNIMED. 1(2). (http://jurnal.unimed.ac.id, Download March 28 ${ }^{\text {th }}$, 2016). 
Atmono, H. D., Rasyidah, U., \& Kasyulita E. (2015). An Analysis of Students' Writing Skill In Descriptive Text of the Second Year Students at SMPN 2 Bangun Purba. E-Journal Universitas Pasir Pangaraian. 1(1). (http://e-journal.upp.ac.id, Download March $10^{\text {th }}, 2017$ ).

Awaliya, M.R., Ariani, M., \& Andayani, T. M. A. (2014). The Effect of Using Real Objects or Realia on the Eight Grade Students' Descriptive Paragraph Writing Achievement at SMP Argopuro 2 Suci Panti Jember in 2013/2014 Academic Year. UPT Perpustakaan Universitas Jember. (http://library.unej.ac.id, Download March 14th, 2017).

Badan Standar Nasional Pendidikan. (2006). Standar Kompetensi dan Kompetensi Dasar SMP/MTs. Jakarta: Badan Standar Nasional Pendidikan.

Brown, H. D. (2001). Teaching by Principles: An Interactive Approach to Language Pedagogy (Second Edition). New York: Longman.

Gau, H. (2010). Realia: Making Language Real. Berkeley California: Primary Concepts.

Adrienne, H. \& Michael, J. (2000). Fifty Strategies for Teaching English Language Learners Second Edition. New Jersey: Pearson Merrill Prentice Hall.

Markhamah, R, P. \& Sudirman. (2013). Developing Students' Descriptive Text Writing Ability Through Realia. U-JET. 2(2). (http://jurnal.fkip.unila.ac.id, Download June 10 ${ }^{\text {th }}, 2016$ ).

Oshima, A. \& Hogue, A. (1996). Introduction to Academic Writing (Second Edition). Addison Wesley Longman.

Surbakti, F. A. Br \& Saragih, A. (2014). Improving the Students'chievement in Writing Descriptive Text By Using Realia Strategy. Register: Journal of English of Language Teaching of FBS-Unimed. 3(3). (http://jurnal.unimed.ac.id/, Download March 28 ${ }^{\text {th }}$, 2016).

Susanti, K. M., Flora, \& Kadaryanto B. (2015). The Effect of Realia on Student's Speaking Achievement. $U$ JET. 4(6). (http://jurnal.fkip.unila.ac.id, Download March 10 ${ }^{\text {th }}, 2017$ ). 